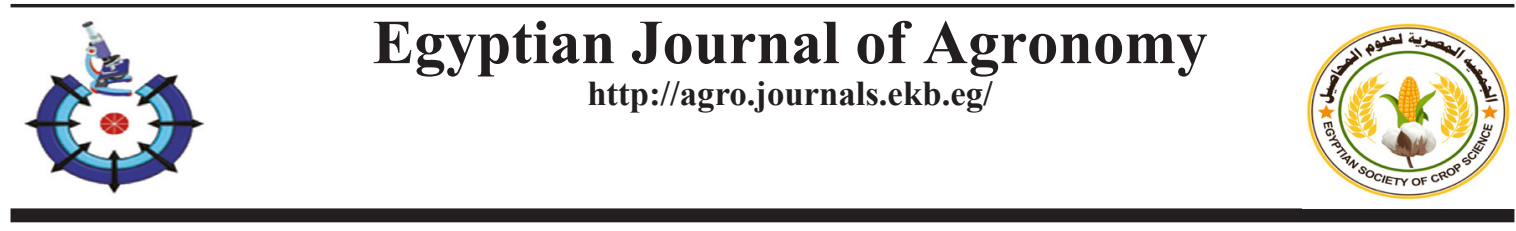

\title{
Evolution of New Guar Variety "BR-21" with High Yield Potential through Pure-line Selection
}

\author{
Rashid Minhas(1), Lal Hussain Akhtar ${ }^{(1)}$, Muhammad Zubair ${ }^{(1) \#, ~ M u h a m m a d ~}$ \\ Shahjahan Bukhari(1), Muhammad Imran Akram ${ }^{(1)}$, Rahmat Ullah ${ }^{(1)}$, \\ Muhammad Sultan Ali Buzmi (2), Abdul Jabbar ${ }^{(2)}$, Muhammad Sohaib Akhtar ${ }^{(3)}$, \\ Abdul Wahab Chughtai ${ }^{(3)}$ \\ (1) Agricultural Research Station (ARS), Bahawalpur, Pakistan; (2) Fodder Research \\ Institute (FRI), Sargodha, Pakistan; ${ }^{(3)}$ Islamia University Bahawalpur (IUB), Pakistan.
}

\begin{abstract}
UAR is a drought tolerant, summer annual legume, well adapted to arid and semi-arid regions of Pakistan. Guar gum is important product which is obtained from guar seed and has worldwide uses in different industries. Therefore, there is a dire need of evolution of new high yielding, short duration and early maturing varieties of guar. Keeping in view the above facts, Agricultural Research Station, Bahawalpur is conducting research to develop new varieties. The present newly developed variety BR-21 (strain name S-5823) is high yielding, short duration, non-hairy with a wider range of adaptability. Yield data (grain yield) were collected from the guar varietal performance trials conducted over eight consecutive years (2011-2020). This strain performed better when evaluated/tested in 7 different yield performance trails including commercial variety as a check from year 2013-2018. The BR21 also performed excellent in the agronomic trials (Sowing date, fertilizer requirement, row spacing, and irrigation levels) compared to check variety in different years of study. Finally, it is concluded that BR-21 is a non-hairy and very easy to harvest than previous guar varieties. It contains high gum contents (34.9\%) than check variety. It is high yielder, early maturing and requires very low inputs. It is comparatively resistant to insect pests and diseases. It is short duration variety, therefore, wheat, raya, chickpea and other Rabi crops can be sown well in time.
\end{abstract}

Keywords: Drought tolerant, Guar, Guar gum, Non-hairy, Pure line selection.

\section{Introduction}

Guar, cluster bean [Cyamopsis tetragonoloba (L.) Taub.] is a drought tolerant, summer annual legume, well adapted to arid and semi-arid regions of Pakistan. Guar plant has long history with different uses and cultivated in many countries other than Pakistan. Guar plant is used as a food, forage and green manure (Abidi et al., 2015). The important product obtained from guar seed having worldwide countless uses in different industries is guar gum (Cook \& Perrin, 2016). Guar gum is used as a lubricant, binder, thickener and emulsifier in different industries. In recent years, guar gum is being used in oil and gas industry, where it is used as a lubricant in the process of hydraulic fracking. The United States is main consumer and importer of guar gum and its products in the world (Singla et al., 2016). Pakistan and India are the top most guar producer countries in the world (Yadav \& Shalendra, 2015). Being a legume crop, roots of guar plant form a symbiotic relationship with Rhizobia bacteria present in the soil and form nodules which fix the atmospheric $\mathrm{N}$ into soil that is utilized by the guar plant as well as subsequent crops.

On account of industrial value, guar seed has great demand from foreign countries like USA, Britain, France, Germany, Italy, UAE, Lesotho,

\#Corresponding author email: mzf1483@gmail.com

Received 11/6/2021; Accepted 28/7/2021

DOI: 10.21608 /agro.2021.80162.1264

C2021 National Information and Documentation Center (NIDOC) 
South Africa, Hong Kong, China, Japan, Australia etc. Pakistan exports guar to more than 60 countries of the world. Therefore, guar gum is an important source of foreign exchange earnings. World's most of the guar is grown in tropical deserts of Indo-Pak Sub Content. India produces $80 \%$, Pakistan $15 \%$ and only $5 \%$ is produced by the other countries like USA, S. Africa, Sudan and Australia. In Pakistan, $47 \%$ of guar is grown in Punjab, $44 \%$ in Sindh, $4.0 \%$ in KPK and $5.0 \%$ in Balouchistan. Thal and Tharparkar areas of Punjab \& Sindh Provinces, respectively, are the core areas for guar crop as about $75 \%$ of the guar is being produced in these areas.

The districts of Bhakkar, Layyah and Jhang in Punjab are the main guar grown areas because this crop is highly drought tolerant and grows well in water deficient areas of these districts. Therefore, there is no other crop like guar that fits well in cropping patterns of these areas. The average yield of guar in Punjab is very low. The reasons of low productivity are (1) This crop is grown on marginal lands and is treated as minor and ignored crop. (2) Secondly, the pure/quality seed of approved varieties is not available to the farmers as only Punjab Seed Corporation is involved in seed production. (3) Thirdly, the farmers have very little knowledge about the guar varieties and improved production technology of this crop. (4) Adoption of new high yielding varieties is poor because guar farmers are still growing traditional guar types which are low yielders. (5) Being ignored crop, the growers also do not apply any inputs like fertilizer, weedicides, fungicides, Insecticides etc. Therefore, there is a dire need of evolution of new high yielding, short duration and early maturing varieties of guar for general cultivation in rainfed (Thal \& Tharparker) and irrigated areas to facilitate the timely sowing of gram, wheat, raya and other rabi crops.

An increase in crop production depends on three combined efforts a) A variety has potential of significant increase in yield. b) To identify best management practices which play an important role for increasing yield of any crop. c) The interaction of variety and management practices to the environment. Plant breeders develops high yielding varieties on the performance over the different environments. The trails are conducted for the evaluation of variety performance at local and other locations (different environments) to improve the selection of variety. The results of trials were evaluated compared with check varieties in a specific environment usually in different years and multi-environment (Johnson et al., 2018; Lingenfelser et al., 2019). The information collected from varietal trials at local level helps to take the grower decisions according to the local environment. These multi-environment and specific environment evaluations explore the varietal characteristics (maturity, disease tolerance, drought and heat tolerance, etc), management practices (water regime, sowing date, etc) (Zubair et al., 2017; Arief et al., 2019).

Plant breeding is a continuous process which consists of different methods for the creation of variability, selection of desirable traits and fixes superior traits in term of breeding objectives (Moose \& Mumm, 2008). Mostly, each breeding programme takes 8-10 years of cycle from initial cross to approval of new variety. During this cycle, selection plays an important role in the development of variety. Selection in plant breeding is a basic technique used by plant breeders for the improvement of crop. It is basically acts of discriminating from variations to select and advance the desirable plants. Sometime, selection is preceded from the individual plant; other time a group of identical plants selected to advance the breeding programme. The traits with high heritability are selected in early generation, while traits with low heritability are selected in later generations when these characters have been fixed in lines (Collard \& Mackill, 2008).

Keeping in view the above facts, Agricultural Research Station, Bahawalpur is conducting research to develop high yielding, early maturing, drought tolerant and disease and insect resistant varieties of guar with high gum contents. The present newly developed variety BR-21 that is high yielding, short duration, non-hairy (easy to harvest than existing varieties of guar namely $2 / 1$, BR-90, BR-99 and BR-2017) and has also a wide range of adaptability.

\section{Material and Methods}

\section{Study region}

Climate analysis showed that Bahawalpur division is located in the region of Pakistan where drought conditions occurred. Bahawalpur is the region with increase in annual temperature with low precipitation (Ali et al., 2020). 


\section{Crop management}

Yield data (grain yield) were collected from the guar varietal performance trials conducted over eight consecutive years (2011-2020). The initial experiments conducted at 7 different locations with 130 genotypes, included both commercial varieties as check and advance lines. All information are retrieved from the agronomic trials 1) Sowing date trial. 2) Water regime, comprising drought or irrigated trials. 3) The trial conducted for grain only or dual purpose (i.e. for grazing and grain purpose). The data set did not include the trials that failed due to environment hazards or disease attack. The trials conducted during this study were conducted at farmers' fields and at research stations.

\section{Variety traits}

We collected all information related to agronomic traits and disease/insect resistance reaction. The information collected on 10 agronomic traits per variety and divided each trait into three category levels. So, we also collect information of each variety reaction against diseases and insect pest resistance and divided the reaction into five scores from 1-5 (1= Susceptible $\& 5=$ Resistant $)$.

Parentagel Pedigree: The guar strain "S-5823" was developed by single plant selection from gene pool Line No. "PGRI-22168" with following salient characters (Table 1) with the participation of several researchers at Agricultural Research Station, Bahawalpur.

TABLE 1. Salient characters

\begin{tabular}{|c|c|c|}
\hline Characters & $\begin{array}{c}\text { Advance Line } \\
(\mathrm{S}-5823)\end{array}$ & $\begin{array}{l}\text { BR-2017 } \\
\text { (Check) }\end{array}$ \\
\hline Plant surface & $\begin{array}{l}\text { Hairless } \\
\text { (glabrous) }\end{array}$ & $\begin{array}{c}\text { hairy } \\
\text { (pubescent) }\end{array}$ \\
\hline Plant height $(\mathrm{cm})$ & $160-180$ & $150-160$ \\
\hline No. of branches plant ${ }^{-1}$ & $0-1$ & $0-1$ \\
\hline $\begin{array}{l}\text { Days to flowering } \\
(50 \%)\end{array}$ & $45-50$ & $50-55$ \\
\hline $\begin{array}{l}\text { Days to } 90 \% \text { pods } \\
\text { maturity }\end{array}$ & $110-120$ & $120-130$ \\
\hline Pods plant ${ }^{-1}$ & $300-350$ & $250-300$ \\
\hline Seed size & Bold & $\begin{array}{l}\text { Medium } \\
\text { bold }\end{array}$ \\
\hline Seed pod ${ }^{-1}$ & $7-10$ & $7-8$ \\
\hline Seed yield & $2400 \mathrm{~kg}$ & $2300 \mathrm{~kg}$ \\
\hline
\end{tabular}

\section{Breeding history}

The S-5823 has been developed at Agricultural Research Station, Bahawalpur through single plant selection from genepool Line No. "PGRI22168 " of guar on the basis of plant type, number of pods plant $^{-1}$, days to $90 \%$ pods maturity, drought tolerance and resistance to insect pests and diseases. The breeding history of the new guar strain is given in Table 2.

TABLE 2. Breeding history of S-5823 selected from gene pool line No. PGRI-22168 during eight growing seasons

\begin{tabular}{|c|c|c|}
\hline Year & Generation/trial & V. Code \\
\hline 2011-12 & Single plant selection & S-5823 \\
\hline $2012-13$ & $\begin{array}{l}\text { Identification of } \\
\text { promising progeny lines } \\
\text { of guar }\end{array}$ & S-5823 \\
\hline $2013-14$ & $\begin{array}{l}\text { Preliminary guar yield } \\
\text { trials (A-Trial) }\end{array}$ & S-5823 \\
\hline $2014-15$ & $\begin{array}{l}\text { Regular guar yield trials } \\
\text { (B-Trial) }\end{array}$ & S-5823 \\
\hline $2015-16$ & $\begin{array}{c}\text { Advance guar yield trials } \\
\text { (C-Trial) }\end{array}$ & S-5823 \\
\hline $2016-17$ & $\begin{array}{l}\text { Zonal trial, NUGYT, } \\
\text { DUS, agronomic trials }\end{array}$ & S-5823 \\
\hline $2017-18$ & $\begin{array}{l}\text { Zonal trial, NUGYT, } \\
\text { DUS, agronomic trials }\end{array}$ & S-5823 \\
\hline 2018-19 & $\begin{array}{l}\text { Spot examination, seed } \\
\text { multiplication }\end{array}$ & S-5823 \\
\hline
\end{tabular}

NUGYT: National uniform guar yield Trial; DUS: Distinguish, uniformity, stability test.

\section{Breeding method and procedure}

1. A pure-line selection method is used in which single plant selections were made from unimproved material in a large numbers as the resources of the breeder.

2. A progeny rows were sowed from the seeds of each selected plant. Better performing rows were selected.

3. The selected rows were tested in replicated trials on the basis of yield and other traits. The rows found to be high yielding with better performing characters were selected for further tests (Fig. 1). 


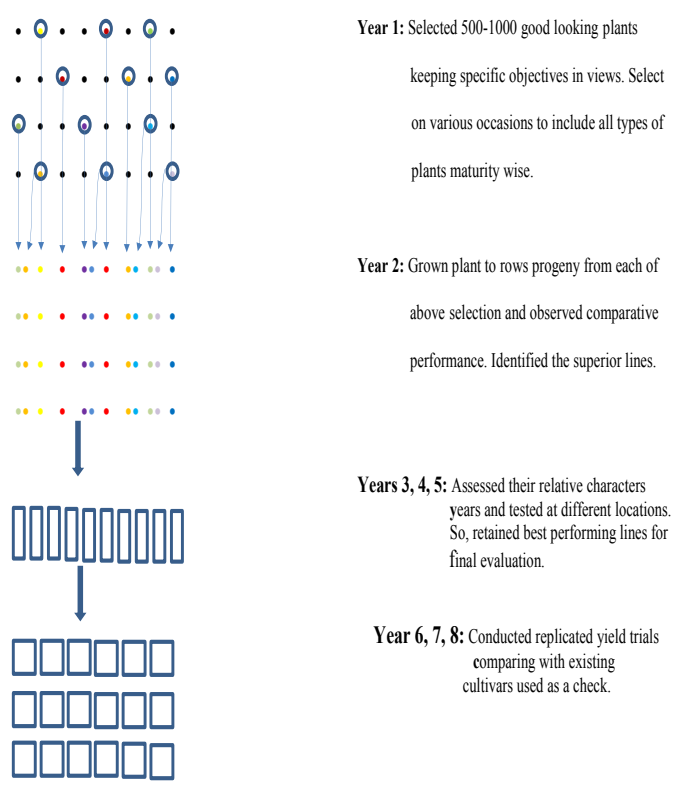

Fig. 1. Procedure of pure-line selection method

\section{Results and Discussion}

\section{Yield performance}

Yield performance in station yield trials

The strain was evaluated/tested in Preliminary Guar Yield Trial (A-Trial), Regular Guar Yield Trial (B-Trial) and Advance Guar Yield Trial (C-Trial) at Agricultural Research Station, Bahawalpur from 2013-14 to 2015-16 and the results are given (Table 3 ).

The strain gave $40.4 \%$ to $65.5 \%$ higher yield than checks. The yield of S-5823 was significantly higher from the check variety (BR-99) over three years in successive A, B and C Trials.

Yield performance in zonal guar yield trial

The trial was conducted at 3 locations at Agronomic Research Stations Khanewal, Bahawalpur and Karore Lal Eison for two consecutive years. The yield data are given (Table 4).

The strain S-5823 was performed excellent and gave significantly higher yield at all three locations over the check variety BR-2017. The performance of S-5823 was excellent at ARS, Bahawalpur location as compared to other two locations during both years of study.

Yield performance in national uniform guar yield trial

The trial was conducted by the National Coordinator (Fodder), National Agriculture Research Council, Islamabad to assess the yield potential of S-5823 at different locations for two years. The yield data are given (Tables $5 \& 6$ ). The strain gave 2.00 to $2.33 \%$ higher yield than check.

Yield evaluation under drought stress conditions

The yield potential of S-5823 was also assessed under drought stress conditions for areas experiencing water shortage. No irrigation was applied from sowing till harvesting except soaking dose (irrigate the field before land preparation). The strain S-5823 gave higher yield over check variety BR-2017 when tested in drought stress conditions and performance of S-5823 was remained statistically significant during 2017-18 year of study with no irrigation only soaking dose. The overall performance of S-5823 was higher in drought stress and normal irrigation levels during both years of study (Table 7).

\section{Agronomic studies}

Sowing date trial

The sowing date trials were conducted for two years during 2016-17 to 2017-18 to find out optimum sowing time of guar strain S-5823 at Agricultural Research Station, Bahawalpur. The results on the basis of average yield of two years are presented (Table 8).

The results obtained showed that S-5823 gave maximum grain yield when sown on $1^{\text {st }}$ June followed by $15^{\text {th }}$ June. Therefore, its sowing is recommended in $1^{\text {st }}$ June. The sowing date from $15^{\text {th }}$ May to $15^{\text {th }}$ June gave maximum yield than other sowing dates but statistically least significant difference was observed between these sowing dates.

TABLE 3. Results of station yield trials (2013-14 to 2015-16)

\begin{tabular}{|c|c|c|c|c|c|}
\hline \multirow{2}{*}{ Years } & \multirow{2}{*}{ Trials } & \multicolumn{2}{|c|}{ Grain Yield $\left(\mathrm{kg} \mathrm{ha}^{-1}\right)$} & \multirow{2}{*}{$\begin{array}{c}\% \text { Increase over } \\
\text { check }\end{array}$} & \multirow{2}{*}{ LSD (0.05) } \\
\hline & & S-5823 & BR-99 (Check) & & \\
\hline 2013-14 & A-Trial & $2075 a$ & $1346 b$ & 54.2 & 203.55 \\
\hline $2014-15$ & B-Trial & $2378 \mathrm{a}$ & $1440 \mathrm{~b}$ & 65.5 & 165.75 \\
\hline $2015-16$ & C-Trial & $2443 a$ & $1740 \mathrm{~b}$ & 40.4 & 224.10 \\
\hline
\end{tabular}

Egypt. J. Agron. 43, No. 2 (2021) 
TABLE 4. Results of zonal guar yield trial (2017-18 to 2018-19)

\begin{tabular}{|c|c|c|c|c|c|}
\hline \multirow[b]{2}{*}{ Years } & \multirow[b]{2}{*}{ Varieties } & \multicolumn{3}{|c|}{ Locations/ grain yield $\left(\mathrm{kg} \mathrm{ha}^{-1}\right)$} & \multirow{2}{*}{$\begin{array}{l}\text { Average } \\
\operatorname{kg}\left(\mathrm{ha}^{-1}\right)\end{array}$} \\
\hline & & $\begin{array}{c}\text { ARS, } \\
\text { Khanewal }\end{array}$ & ARS , Karor & $\begin{array}{c}\text { ARS, } \\
\text { Bahawalpur }\end{array}$ & \\
\hline \multirow{2}{*}{$2016-17$} & S-5823 & 1764 & 1462 & 2416 & $1881 \mathrm{~A}$ \\
\hline & BR-2017 (Check) & 1399 & 853 & 1945 & $1399 \mathrm{~B}$ \\
\hline Mean & & $1582 \mathrm{~B}$ & $1158 \mathrm{C}$ & $2181 \mathrm{~A}$ & \\
\hline LSD & \multicolumn{2}{|c|}{ Variety $=213.91$} & \multicolumn{2}{|c|}{ Location $=301.94$} & Variety $\mathrm{x}$ Location $=370.50$ \\
\hline \multirow{2}{*}{$2017-18$} & S-5823 & 2160 & 1233 & 2218 & $1870 \mathrm{~A}$ \\
\hline & BR-2017 (Check) & 1694 & 905 & 1840 & $1480 \mathrm{~B}$ \\
\hline Mean & & $1927 \mathrm{~A}$ & $1069 \mathrm{~B}$ & $2029 \mathrm{~A}$ & \\
\hline LSD & \multicolumn{2}{|c|}{ Variety $=213.93$} & \multicolumn{2}{|c|}{ Location $=301.84$} & Variety $\mathrm{x}$ Location $=398.90$ \\
\hline
\end{tabular}

TABLE 5. Results of national uniform guar yield trial of Kharif 2018

\begin{tabular}{lccccc}
\hline \multirow{2}{*}{ Entry Name } & \multicolumn{5}{c}{ Locations/ grain Yield (kg ha-1) } \\
\cline { 2 - 6 } & $\begin{array}{c}\text { BARS, } \\
\text { Fatejhang }\end{array}$ & $\begin{array}{c}\text { AZRI, } \\
\text { Bhakkar }\end{array}$ & $\begin{array}{c}\text { Rice Res. Stn. B. } \\
\text { Nagar }\end{array}$ & $\begin{array}{c}\text { AZRI } \\
\text { Bahawalpur }\end{array}$ & Av. \\
\hline S-5823 & 1885 & 1428 & 1852 & 1100 & 1566 \\
BR-2017 (Check) & 1549 & 1373 & 1958 & 1263 & 1536 \\
Increase over check (\%) & 21.70 & 4.01 & -5.41 & -12.90 & 2.00 \\
\hline
\end{tabular}

TABLE 6. Results of national uniform guar yield trial of Kharif 2019

\begin{tabular}{lcccccc}
\hline \multirow{2}{*}{ Entry Name } & \multicolumn{5}{c}{ Locations/ grain yield (kg ha-1) } \\
\cline { 2 - 7 } & $\begin{array}{c}\text { BARS, } \\
\text { Fatejhang }\end{array}$ & $\begin{array}{c}\text { AZRI } \\
\text { Bhakkar }\end{array}$ & $\begin{array}{c}\text { BARI, } \\
\text { Chakwal }\end{array}$ & $\begin{array}{c}\text { CRI, } \\
\text { Khanpur }\end{array}$ & $\begin{array}{c}\text { AZRI } \\
\text { Bahawalpur }\end{array}$ & Av. \\
\hline S-5823 & 3500 & 1100 & 2136 & 1879 & 1689 & 2061 \\
BR-2017 (Check) & 3674 & 881 & 1909 & 1698 & 1909 & 2014 \\
Increase over check (\%) & -4.70 & 24.90 & 11.90 & 10.70 & -11.50 & 2.33 \\
\hline
\end{tabular}

TABLE 7. Results of drought stress trials (2017-18 \& 2018-19)

\begin{tabular}{lccc}
\hline \multirow{2}{*}{ Years } & Strains & \multicolumn{2}{c}{ Grain yield $\left(\mathbf{k g ~ h a}^{-1}\right)$} \\
\cline { 3 - 4 } & & No irrigation after sowing & 3 irrigations after sowing \\
\hline \multirow{2}{*}{$2017-18$} & S-5823 & $1576 \mathrm{a}$ & $2362 \mathrm{a}$ \\
& BR-2017 (Check) & $1350 \mathrm{~b}$ & $2387 \mathrm{a}$ \\
& LSD $(0.05)$ & 191.57 & 286.32 \\
$2018-19$ & S-5823 & $1498 \mathrm{a}$ & $2422 \mathrm{a}$ \\
& BR-2017 (Check) & $1405 \mathrm{a}$ & $2246 \mathrm{a}$ \\
& LSD $(0.05)$ & 147.22 & 356.61 \\
\hline
\end{tabular}

TABLE 8. Effect of sowing dates on grain yield of S-5823

\begin{tabular}{lccc}
\hline \multirow{2}{*}{ Treatments/ sowing dates } & \multicolumn{2}{c}{ Grain yield $\left(\mathbf{k g ~ h a}^{-1}\right)$} & \multirow{2}{*}{ Average } \\
\cline { 2 - 3 } & $\mathbf{2 0 1 6 - 1 7}$ & $\mathbf{2 0 1 7 - 1 8}$ & 1586 \\
D1 (01/05) & $1666 \mathrm{~b}$ & $1505 \mathrm{~b}$ & 2122 \\
D2 (15/05) & $2050 \mathrm{a}$ & $2193 \mathrm{a}$ & $\mathbf{2 3 8 6}$ \\
D3 (01/06) & $\mathbf{2 3 1 7 \mathbf { a }}$ & $\mathbf{2 4 5 5 a}$ & 2222 \\
D4 (15/06) & $2270 \mathrm{a}$ & $2174 \mathrm{a}$ & 1773 \\
D5 (01/07) & $1805 \mathrm{c}$ & $1740 \mathrm{c}$ & 1502 \\
D6 (15/07) & $1437 \mathrm{~d}$ & $1567 \mathrm{~d}$ & \\
LSD $(0.05)$ & 393.60 & 432.26 & \\
\hline
\end{tabular}




\section{Fertilizer requirement}

The response of S-5823 was studied at 10 different levels of NPK for two years during 201617 to 2017-18 to find out optimum fertilizer doze at Agricultural Research Station, Bahawalpur. The results on the basis of average yield of two years are presented in Table 9.

The results obtained revealed that the strain S-5823 gave maximum yield at fertilizer doze of 30:60:60 NPK kg ha-1.

\section{Row spacing}

The results of sowing of S-5823 at different row spacing are shown in Table 10 which indicates that sowing of crop at $45 \mathrm{~cm}$ apart is most appropriate to get better grain yield.

Water requirements under irrigated conditions

Five different irrigations were applied to S-5823 from sowing till harvesting of crop to find out optimum number of irrigations in order to get maximum grain yield in irrigated areas. The results obtained showed that strain S-5823 produced maximum grain yield with three irrigations after sowing i.e. after 35 days of sowing, at flowering stage and at pod formation stage (Table 11).

\section{Entomological studies}

The response of S-5823 to insect pests attack was studied at the Entomology Section, Regional
Agricultural Research Institute, Bahawalpur during Kharif, 2016-17 and 2017-18. The insect pest data recorded by the Entomologist for two growing seasons are given.

The data recorded indicated that only attack of sucking pests i.e. whitefly and jassid was observed in traces and the strain S-5823 showed more tolerance to insect pests infestation compared with check variety BR-2017 (Table 12).

\section{Pathological studies}

The disease reaction of S-5223 was studied at the Plant Pathology Section, Regional Agricultural Research Institute, Bahawalpur during Kharif, 2016-17 and 2017-18. The data regarding disease incidence recorded by the Plant Pathologist for two consecutive years are given as in Table 13

The plant Pathologist observed the attack of two diseases, i.e. bacterial blight and alternaria blight. The data given in the above table revealed that strain S-5823 was resistant against alternaria blight and moderately resistant against bacterial blight as compared to the check variety, i.e. BR2017.

\section{Quality analysis}

The results given in the Table 14 revealed that the gum contents of S-5823 are comparatively better than the check variety BR-2017.

TABLE 9. Results of NPK fertilizer trial

\begin{tabular}{|c|c|c|c|c|c|c|}
\hline \multirow{2}{*}{ Treatments } & \multirow{2}{*}{$\begin{array}{c}\mathrm{N} \\
\left(\mathrm{kg} \mathrm{ha}^{-1}\right)\end{array}$} & \multirow{2}{*}{$\begin{array}{c}\mathbf{P} \\
\left(\mathrm{kg} \mathrm{ha}^{-1}\right)\end{array}$} & \multirow{2}{*}{$\begin{array}{c}\mathrm{K} \\
\left(\mathrm{kg} \mathrm{ha}^{-1}\right)\end{array}$} & \multicolumn{2}{|c|}{ Grain yiled $\left(\mathrm{kg} \mathrm{ha}^{-1}\right)$} & \multirow{2}{*}{ Average } \\
\hline & & & & 2016-17 & 2017-18 & \\
\hline $\mathrm{T} 1$ & 0 & 0 & 0 & $1090 \mathrm{~b}$ & $1135 b$ & 1113 \\
\hline T 2 & 15 & 30 & 30 & $1283 c$ & $1392 \mathrm{c}$ & 1338 \\
\hline Т 3 & 15 & 60 & 30 & $1476 \mathrm{~d}$ & $1531 d$ & 1504 \\
\hline $\mathrm{T} 4$ & 15 & 90 & 30 & $1700 \mathrm{e}$ & $1656 \mathrm{e}$ & 1678 \\
\hline Т 5 & 30 & 30 & 60 & $1984 a$ & 2049f & 2017 \\
\hline T 6 & 30 & 60 & 60 & $2410 a$ & $2499 a$ & 2455 \\
\hline $\mathrm{T} 7$ & 30 & 90 & 60 & $2255 \mathrm{a}$ & $2452 \mathrm{a}$ & 2354 \\
\hline Т 8 & 45 & 30 & 90 & $2100 \mathrm{a}$ & $2070 \mathrm{~g}$ & 2085 \\
\hline T9 & 45 & 60 & 90 & $1905 f$ & $2060 \mathrm{~h}$ & 1983 \\
\hline $\mathrm{T} 10$ & 45 & 90 & 90 & $1836 \mathrm{~g}$ & $1980 \mathrm{i}$ & 1908 \\
\hline $\operatorname{LSD}(0.05)$ & & & & 445.72 & 366.16 & \\
\hline
\end{tabular}

TABLE 10. Effect of different row spacing on grain yield of S-5823

\begin{tabular}{|c|c|c|c|c|}
\hline \multirow{2}{*}{\multicolumn{2}{|c|}{ Treatments/ row spacing }} & \multicolumn{2}{|c|}{ Grain yield $\left(\mathrm{kg} \mathrm{ha}^{-1}\right)$} & \multirow{2}{*}{ Average } \\
\hline & & 2016-17 & 2017-18 & \\
\hline T1 & $30 \mathrm{~cm}$ & 1988 & 2045 & 2017 \\
\hline $\mathrm{T} 2$ & $45 \mathrm{~cm}$ & 2386 & 2408 & 2397 \\
\hline T3 & $60 \mathrm{~cm}$ & 1692 & 1853 & 1773 \\
\hline $\operatorname{LSD}(0.05)$ & & 643.94 & 527.46 & \\
\hline
\end{tabular}

Egypt. J. Agron. 43, No. 2 (2021) 
TABLE 11. Response of S-5823 to different irrigation levels

\begin{tabular}{lcccc}
\hline & Treatments/ irrigation levels & \multicolumn{2}{c}{ Grain yield $\left(\mathbf{k g ~ h a}^{-1}\right)$} & \multirow{2}{*}{ Average } \\
\cline { 3 - 4 } & One irrigation a/f 35 days of sowing & $\mathbf{2 0 1 6 - 1 7}$ & $\mathbf{2 0 1 7 - 1 8}$ & \\
\hline T1 & One irrigation at flowering stage & 1519 & 1590 & 1555 \\
T2 & (T1+T2) & 1380 & 1463 & 1422 \\
T3 & T3+ irrigation at pod formation stage & 1925 & 1863 & 1894 \\
T4 & No irrigation (Control) & 2405 & 2533 & 2469 \\
T5 & LSD (0.05) & 1467 & 1394 & 1431 \\
& & 569.26 & 455.82 & \\
\hline
\end{tabular}

TABLE 12. Response of S-5823 against insect pests attack

\begin{tabular}{lcccc}
\hline \multirow{2}{*}{ Varieties } & \multicolumn{2}{c}{$\mathbf{2 0 1 6 - 1 7}$} & \multicolumn{2}{c}{$\mathbf{2 0 1 7 - 1 8}$} \\
\cline { 2 - 5 } & Jassid leaf $^{\mathbf{1}}$ & Whitefly leaf $^{\mathbf{1}}$ & Jassid leaf $^{\mathbf{1}}$ & Whitefly leaf $^{\mathbf{1}}$ \\
\hline S-5823 & 0.83 & 4.13 & 0.95 & 2.50 \\
BR-2017 (check) & 1.06 & 4.90 & 1.20 & 5.50 \\
LSD (0.05) & 0.22 & 1.20 & 0.35 & 1.90 \\
\hline
\end{tabular}

TABLE 13. Response of S-5823 against diseases

\begin{tabular}{|c|c|c|c|c|}
\hline \multirow{2}{*}{ Varieties } & \multicolumn{2}{|c|}{ 2016-17 } & \multicolumn{2}{|c|}{$2017-18$} \\
\hline & Bacterial Blight & Alternaria Blight & Bacterial Blight & Alternaria Blight \\
\hline S-5823 & $\begin{array}{l}\text { Moderately } \\
\text { Susceptible }\end{array}$ & Resistant & Moderately Resistant & Resistant \\
\hline $\begin{array}{l}\text { BR-2017 } \\
\text { (Check) }\end{array}$ & $\begin{array}{l}\text { Moderately } \\
\text { Susceptible }\end{array}$ & Moderately Resistant & $\begin{array}{l}\text { Moderately } \\
\text { Susceptible }\end{array}$ & Moderately Resistant \\
\hline
\end{tabular}

TABLE 14. Results of chemical analysis

\begin{tabular}{lcc}
\hline Quality Trait & BR-2017 (Check) & S-5823 \\
\hline Gum Contents (\%) & 33.71 & 34.87 \\
Crude Protein (\%) & 30.75 & 30.25 \\
Carbohydrates (\%) & 38.90 & 39.10 \\
Germ+Meal & 41.86 & 38.85 \\
Husk & 9.87 & 9.49 \\
\hline
\end{tabular}

Source: Agricultural Chemist (Bio), Post-Harvest Research Centre, Ayub Agricultural Research Institute, Faisalabad.

Production technology of S-5823

Soil type

Best sowing time

Seed rate

Spacing plant to

plant distance

Row to row

distance

Irrigations

$1^{\text {st }}$ irrigation

$2^{\text {nd }}$ irrigation

$3^{\text {rd }}$ irrigation
Sandy to sandy loam

01 June-15 June

$20-25 \mathrm{~kg} \mathrm{ha}^{-1}$ for line sowing

$30-35 \mathrm{~kg} \mathrm{ha}^{-1}$ for broadcast

6 inches

18 inches

3

35-40 days after sowing

at flowering stage

at pod formation stage
Fertilizer

Plant protection

Harvesting

NPK@30:60:60 Kg ha-1

According to insect pest situation

110-120 days after sowing

\section{Conclusion}

The new variety is a non-hairy and very easy to harvest than previous guar varieties due to its non-hairiness. It contains high gum contents upto $34.9 \%$ which is higher than check variety. It is higher yielder than existing varieties of guar, early maturing and requires very low inputs. It is comparatively resistant to insect pests and diseases. It is short duration variety, therefore, 
wheat, raya, chickpea and other Rabi crops can be sown well in time. It is also drought $\&$ heat tolerant.

\section{References}

Abidi, N., Liyanage, S., Auld, D., Imel, R.K., Norman, L., Grover, K., Angadi, S., Singla, S., Trostle, C. (2015) Chapter 12: Challenges and opportunities for increasing guar production in the United States to support unconventional oil and gas production. In: "Hydraulic Fracturing Impacts and Technologies", Venki Uddameri, Audra Morse, Kay J. Tindle (Eds.), pp. 207-226.

Ali, S.M., Khalid, B., Akhter, A., Islam, A., Adnan, S. (2020) Analyzing the occurrence of floods and droughts in connection with climate change in Punjab province, Pakistan. Natural Hazards, 103(17), 2533-2559.

Arief, V.N., Desmae, H., Hardner, C., DeLacy, I.H., Gilmour, A., Bull, J.K., et al. (2019). Utilization of multiyear plant breeding data to better predict genotype performance. Crop Science, 59(2), 480490.

Collard, B.C.Y., Mackill, D.J. (2008) Markerassisted selection: an approach for precision plant breeding in the twenty-first century. Philosophical Transactions of the Royal Society of London. Series B, Biological Sciences, 363, 557-572.

Cook, T., Perrin, J. (2016) Hydraulic fracturing accounts for about half of current U.S. crude oil production. Today in Energy. U.S. Energy Information Administration.
Johnson, J., Haley, S., Jones, S., Asfeld, E., Meyer, R., Trujillo, W., Kaan, D., Roesch, K., Spring, J., Larson, J., Vigil, M., Pettinger, B., Gaines, T., Westra, E., Shelton, C. (2018) Making Better Decisions - 2018 Colorado Winter Wheat Variety Performance Trials. Fort Collins, CO.

Lingenfelser, J., Schapaugh, W., Hessel, R., Aiken, R., Coltrain, J., Martin, R., Mengarelli, L., Sassenrath, G., Adee, E., Esser, A., Kimball, J., Egbert, V., Rezac, L., Roberds, D., Short, C. (2019) Kansas Performance Tests with Soybean Varieties, SRP1146. Kansas State University Agricultural Experiment Station and Cooperative Extension Service, Manhattan, KS Available at: https:// www.bookstore.ksre.ksu.edu/pubs/ SRP1146.pdf [verified 13 August 2019].

Moose, S.P., Mumm, R.H. (2008) Molecular plant breeding as the foundation for 21st century crop improvement. Plant Physiology, 147, 969-977.

Singla, S., Grover, K., Angadi, S.V., Schutte, B., VanLeeuwen, D. (2016) Guar stand establishment, physiology, and yield responses to planting date in southern New Mexico. Agronomy Journal, 108(6), 2289-2300.

Yadav, H., Shalendra, D. (2015) Guar Outlook 2015 CCS National Institute of Agricultural Marketing, Ministry of Agriculture, Government of India

Zubair M., Akhtar, L.H., Rashid, M., Bukhari, M.S.J. Khalid, M.A.R. (2017) Release of high yielding, early maturing and drought tolerant guar variety BR-2017. International Journal of Biology and Biotechnology, 14(4), 615-621. 